\title{
A Case of Mycobacterial Skin Disease Caused by Mycobacterium peregrinum, and a Review of Cutaneous Infection
}

\author{
Fuminao Kamijo $^{a}$ Hisashi Uhara $^{a}$ Hitomi Kubo $^{b}$ \\ Kazue Nakanaga ${ }^{c}$ Yoshihiko Hoshino $^{c}$ Norihisa Ishii ${ }^{c}$ \\ Ryuhei Okuyama ${ }^{\mathrm{a}}$ \\ ${ }^{a}$ Department of Dermatology, Shinshu University School of Medicine, Matsumoto, \\ ${ }^{b}$ Department of Dermatology, Nagano Red Cross Hospital, Nagano, and \\ 'Leprosy Research Center, National Institute of Infectious Diseases, Tokyo, Japan
}

Key Words

Mycobacterium peregrinum $\cdot$ Rapidly growing mycobacterium $\cdot$ Skin $\cdot$ Therapy

\begin{abstract}
An 83-year-old Japanese man presented with a 2-month history of symptomatic nodules on the left hand. He was not in an immunocompromised condition and reported no causal events. A biopsy specimen demonstrated granulomatous tissue with mixed cell infiltration consisting of neutrophils, histiocytes, lymphocytes, and multinuclear giant cells. No bacillus was detected by PAS, acid-fast stain, immunofluorescent stain or polymerase chain reaction analysis. The isolate was found to be a rapidly growing mycobacterium after 4 weeks of incubation at $25^{\circ} \mathrm{C}$ on an Ogawa egg slant. Mycobacterium peregrinum was isolated by DNADNA hybridization analysis, 16S rRNA gene sequence, and by its production of 3-day arylsulfatase. The patient received $200 \mathrm{mg}$ oral minocycline for 28 weeks. The lesion disappeared after 10 weeks of this treatment.
\end{abstract}

\section{Introduction}

Mycobacterium (M.) peregrinum, an opportunistic, rapidly growing mycobacterium (RGM), belongs to the $M$. fortuitum group. Because patients with cutaneous infection due to M. peregrinum are rare, the clinical information on this mycobacterium is limited $[1,2]$. 


\section{Case Report}

An 83-year-old Japanese man presented with a 2-month history of symptomatic nodules on the left hand. He was not in an immunocompromised condition and reported no causal events related to infection, including preceding trauma, fish breeding or circulating bath. On examination, an erythematous plaque with an ulcer and pustules $3 \mathrm{~cm}$ in size was seen on the dorsal aspect of the left hand (fig. 1). The superficial lymph node was not palpable. The results of laboratory examinations were within the normal range. Chest X-ray ruled out any pulmonary problems. A biopsy specimen from the hand demonstrated granulomatous tissue with mixed cell infiltration consisting of neutrophils, histiocytes, lymphocytes, and multinuclear giant cells (fig. 2). No bacillus was detected by PAS, acid-fast stain, immunofluorescent stain or polymerase chain reaction analysis. The isolate was found to be an RGM after 4 weeks of incubation at $25^{\circ} \mathrm{C}$ on an Ogawa egg slant. M. peregrinum was isolated by DNA-DNA hybridization analysis, 16S rRNA gene sequence, and by its production of 3day arylsulfatase [3].

The patient received $200 \mathrm{mg}$ oral minocycline (MINO) for 28 weeks. The lesion progressively shrank during the treatment and then disappeared after 10 weeks of treatment, leaving only a few scars. No recurrence was observed 1 year after his first visit.

\section{Discussion}

In recent years, the pathogenic potential of RGM has gained attention. Although they are not usually pathogenic in humans, they can cause disease in individuals with or without an immunocompromised condition and in people who have had traumatic accidents, such as tsunami survivors with late-onset skin or soft-tissue infections [4]. $M$. abscessus and $M$. fortuitum are the most commonly detected RGM in skin infections, and M. peregrinum is rarely identified. Thus, the clinical information, especially regarding treatment, has not been fully examined. Table 1 lists the cases of M. peregrinum with skin lesions that have been reported $[2,4-8]$. There were no patients with immunocompromised conditions. All patients were successfully treated with combinations of sparfloxacin (SPFX) and MINO; amikacin (AMK), imipenem-cilastatin (IMP/CS) and levofloxacin (LVFX); AMK, clarithromycin (CAM) and ciprofloxacin (CPFX); and CAM and LVFX, except our patient, who was treated with MINO monotherapy. For treatment of infections caused by $M$. fortuitum group mycobacteria including M. peregrinum, the Johns Hopkins Antibiotics Guide recommends oral monotherapy with sulfonamide, doxycycline (DOXY), or CAM for limited or localized wound infections and the combination of at least 2 agents including AMK plus either a $\beta$-lactam or quinolone for severe infections of the skin, soft tissue or bone, and for pulmonary disease [9]. Han et al. [1] reported that antimicrobial susceptibility varied among the species of RGM. The results in 105 strains showed that AMK was most active against $M$. abscessus, $M$. chelonae and the $M$. fortuitum group. CAM was the second most active drug for most RGM, except in the case of M. fortuitum. Less than half of the strains showed susceptibility to DOXY and MINO, and none of the 6 strains of $M$. peregrinum or Clostridium septicum showed sensitivity to these 2 antibiotics. Because most of these strains were isolated from respiratory sources or blood cultures in cancer patients, the data might not apply to cases of skin infection in patients without an immunocompromised condition. Although monotherapy with MINO was effective in our case, combination therapy should be performed routinely. Further case reports involving clinical evaluations of antibiotics are necessary to determine an appropriate therapy for rare mycobacterial infections. 
Table 1. Patients with M. peregrinum skin lesions

\begin{tabular}{|c|c|c|c|c|c|c|c|c|c|c|c|}
\hline No. & Year & $\begin{array}{l}\text { Age/ } \\
\text { sex }\end{array}$ & Country & $\begin{array}{l}\text { Site of infection } \\
\text { (causing event) }\end{array}$ & Location & $\begin{array}{l}\text { Immuno- } \\
\text { deficiency }\end{array}$ & $\begin{array}{l}\text { Chronic } \\
\text { disease }\end{array}$ & Antibiotics & $\begin{array}{l}\text { Duration of } \\
\text { treatment }\end{array}$ & $\begin{array}{l}\text { Surgical } \\
\text { procedure }\end{array}$ & $\begin{array}{l}\text { Ref } \\
\text { no. }\end{array}$ \\
\hline 1 & 1983 & NR & USA & after mammoplasty & NR & - & NR & NR & NR & NR & 5 \\
\hline 2 & 1998 & $45 / \mathrm{M}$ & Japan & skin and soft tissue & left arm & - & - & SPFX, MINO & 15 weeks & - & 2 \\
\hline 3 & 1998 & NR & France & $\begin{array}{l}\text { skin and soft tissue } \\
\text { (subcutaneous } \\
\text { insulin infusion) }\end{array}$ & NR & - & NR & NR & NR & NR & 6 \\
\hline 4 & 1999 & $>65 / F$ & Japan & skin & NR & NR & NR & NR & NR & NR & 10 \\
\hline 5 & 2003 & $67 / F$ & Japan & skin & $\begin{array}{l}\text { back of } \\
\text { left hand }\end{array}$ & NR & NR & NR & NR & NR & 11 \\
\hline 6 & 2006 & NR & Spain & $\begin{array}{l}\text { skin and soft tissue } \\
\text { (mesotherapy) }\end{array}$ & NR & - & NR & CPFX & 3-4 months & - & 7 \\
\hline 7 & 2009 & $58 / \mathrm{F}$ & Japan & $\begin{array}{l}\text { skin and soft tissue } \\
\text { (reconstruction of } \\
\text { abdominal wall) }\end{array}$ & $\begin{array}{l}\text { right chest } \\
\text { wall }\end{array}$ & - & NR & AMK, IMP/CS, LVFX & 5 weeks & $\begin{array}{l}\text { removal of } \\
\text { artificial } \\
\text { sheet }\end{array}$ & 8 \\
\hline 8 & 2008 & $40 / \mathrm{M}$ & Sweden & skin & NR & - & NR & AMK, CAM, CPFX & 3-6 months? & suture & 4 \\
\hline 9 & 2011 & $78 / \mathrm{M}$ & Japan & skin & $\begin{array}{l}\text { back of } \\
\text { right hand }\end{array}$ & - & $\begin{array}{l}\text { chronic } \\
\text { gastritis }\end{array}$ & CAM, LVFX & 12 weeks & - & 12 \\
\hline $\begin{array}{l}\text { Present } \\
\text { case }\end{array}$ & 2011 & $83 / \mathrm{M}$ & Japan & skin & $\begin{array}{l}\text { back of } \\
\text { left hand }\end{array}$ & - & hypertension & MINO & 28 weeks & - & \\
\hline
\end{tabular}

$\mathrm{NR}=$ Not recorded

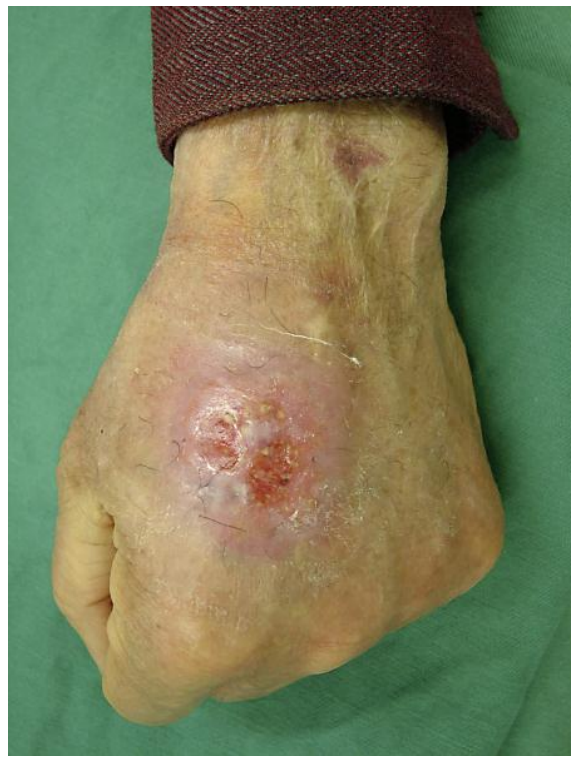

Fig. 1. Plaque with ulcer on the left hand. 

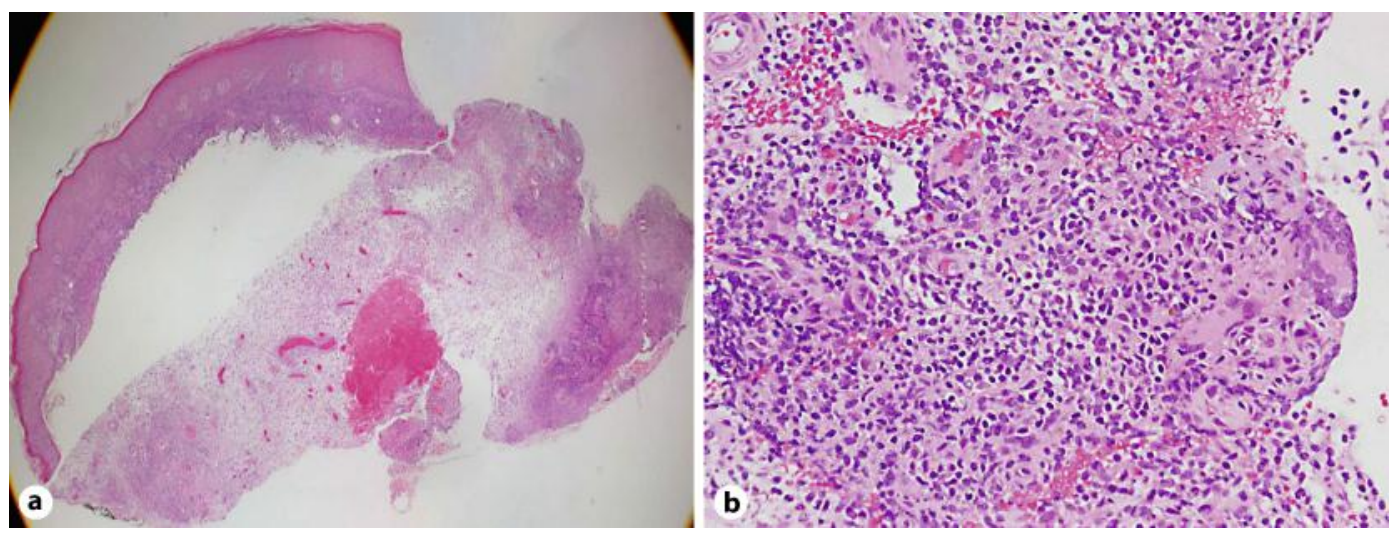

Fig. 2. Biopsy specimen demonstrated granulomatous tissue with mixed cell infiltration consisting of neutrophils, histiocytes, lymphocytes, and multinuclear giant cells.

\section{References}

1 Han XY, De I, Jacobson KL: Rapidly growing mycobacteria: clinical and microbiologic studies of 115 cases. Am J Clin Pathol 2007;128:612-621.

$\checkmark 2$ Ishii N, Sugita Y, Sato I, Nakajima H: A case of mycobacterial skin disease caused by Mycobacterium peregrinum and M. scrofulaceum. Acta Derm Venereol 1998;78:76-77.

-3 Nakanaga K, Hoshino Y, Era Y, et al: Multiple cases of cutaneous Mycobacterium massiliense infection in a 'hot spa' in Japan. J Clin Microbiol 2011;49:613-617.

-4 Appelgren P, Farnebo F, Dotevall L, Studahl M, Jonsson B, Petrini B: Late-onset posttraumatic skin and soft-tissue infections caused by rapid-growing mycobacteria in tsunami survivors. Clin Infect Dis 2008;47:e11-e16.

5 Clegg HW, Foster MT, Sanders WE Jr, Baine WB: Infection due to organisms of the Mycobacterium fortuitum complex after augmentation mammaplasty: clinical and epidemiologic features. J Infect Dis 1983;147:427-433.

-6 Pagnoux C, Nassif X, Boitard C, Timsit J: Infection of continuous subcutaneous insulin infusion site with Mycobacterium peregrinum. Diabetes Care 1998;21:191-192.

$\rightarrow 7$ Rivera-Olivero IA, Guevara A, Escalona A, et al: Soft-tissue infections due to non-tuberculous mycobacteria following mesotherapy. What is the price of beauty? (in Spanish). Enferm Infecc Microbiol Clin 2006;24:302-306.

8 Nagao M, Sonobe M, Bando T, et al: Surgical site infection due to Mycobacterium peregrinum: a case report and literature review. Int J Infect Dis 2009;13:209-211.

9 Johns Hopkins Antibiotics Guide. Available at: http://www.hopkinsguides.com/hopkins/ub (last accessed 28 February, 2012).

10 Kamo A, Takahashi H, Sakata F, et al: A case of skin infection by Mycobacterium peregrinum (in Japanese). Jpn J Med Technol 1999;48:660.

11 Takahashi K, Fukami Y, Asanao K, et al: A case of Mycobacterial skin infection by Mycobacterium peregrinum. Jpn J Dermatol 2003;113:1569-1570.

12 Yamamoto T, Matsudate Y, Urano Y, et al: A case of skin infection by two kind of Mycobacterium. Nishinihon J Dermatol 2011;73:107. 